\title{
Community-Based Survey of Unwanted Pregnancy in Southwestern Nigeria
}

\author{
Boniface A Oye-Adeniran ${ }^{1,6}$, Isaac F Adewole ${ }^{2,6}$, Augustine V Umoh', Ekanem E Ekanem ${ }^{4}$, Abidoye \\ Gbadegesin ${ }^{5}$ and Nozi Iwere ${ }^{6}$
}

\begin{abstract}
Unwanted pregnancy, and consequently unsafe abortion, remains major reproductive health problems in Nigeria that needs to be tackled. Unfortunately, there is a dearth of information on this problem at the community level. This study therefore examined the prevalence of unwanted pregnancy in the community as well as associated factors including the views, perceptions and attitudes of community members towards unwanted pregnancy and the pattern of help-seeking behaviour on unwanted pregnancy. Information was obtained from 3,743 women in urban and rural communities in two Nigerian states of Lagos and Edo. At some point in life, $26.6 \%$ of the respondents had had unwanted Pregnancy while abortion prevalence was $21.7 \%$. Short birth intervals (21.1\%), high cost of raising children (20.1\%), interruption of education (20.1\%) and being unmarried (17.3\%) were the most common reasons for not wanting pregnancies. Most of the respondents (91.3\%) were aware of some form of contraception but ever-use rate was only $36.6 \%$ while current use rate was $23.4 \%$. Both abortion and contraceptive use were significantly associated with increasing levels of education. Unwanted pregnancy constitutes a problem even at the community level and more research is needed to understand the persistent disparity between contraceptive knowledge and usage, as increased usage will reduce unwanted pregnancy and induced abortion. (Afr J Reprod Health 2004; $8[3]: 103-115)$
\end{abstract}

\section{RÉSUMÉ}

Enquête à base communautaire sur la grossesse non-désirée au sud-ouest du Nigéria. La grossesse non-désirée et par conséquence l'avortement à risque, demeure un des problèmes majeurs de la santé de reproduction qu'on devrait aborder. Malheureusement, il y a une pauvreté de renseignement à l'égard de ce problème au niveau de la communauté. Cette étude a donc examiné la prévalence de la grossesse non-désirée dans la communauté ainsi que les facteurs qui y sont associés, y compris des points de vue, des perceptions et attitudes des membres de la communauté envers la grossesse non-désirée et les traits comportementaux du nécessitaux sur la grossesse non-désirée. Nous avons recueilli des renseignements auprès des 3,743 femmes dans des communautés rurales et urbaines dans deux Etats nigérians que sont Lagos et Edo. A un certain moment de leur vie, $26 \%$ des répondants avaient eu des grossesse non-désirées alors que la prévalence de l'avortement était de 21,7\%. De courts intervales de maissance $(21,1 \%)$, de coût considérable de l'éducation des enfants $(20,1 \%)$ l'interruption de la scolarité $(20,1 \%)$ et le fait d'être célibataire (17,3\%) étaient les raisons les plus communes données pour ne pas vouloir des grossesses. La plupart des répondantes $(91,3 \%)$ étaient conscientes d'une forme ou d'une autre du contraceptif, mais le taux d'usage n'était que de 36,6\% alors que le taux d'usage courant était de 23,4\%. Et l'avortement et l'usage du contraceptif ont été liés de manière significative aux niveau croissants de scolarisation. La grossesse non-désirée constitue un problème même au niveau de la communauté et il faut davantage de recherche pour comprendre la disparité persistente entre la connaissaince du contraceptif et l'usage, puisque l'usage accru réduira la grossesse non-désirée et l'avortement provoqué. (Rev Afr Santé Reprod 2004; $8[3]: 103-115)$

KEY WORDS: Community-based survey, southwestern Nigeria, unwanted pregnancy, abortion, contraception

\footnotetext{
${ }^{1}$ Department of Obstetrics \& Gynaecology, College of Medicine, University of Lagos, Lagos, Nigeria. ${ }^{2}$ Department of Obstetrics \& Gynaecology, College of Medicine, University of Ibadan, Ibadan, Nigeria. ${ }^{3}$ Department of Obstetrics \& Gynaecology, University of Uyo Teaching Hospital, Uyo, Nigeria. ${ }^{4}$ Department of Community Health, College of Medicine, University of Lagos, Lagos, Nigeria. ${ }^{5}$ Department of Obstetrics \& Gynaecology, Ayinke House, Lagos State University Teaching Hospital, Ikeja, Lagos, Nigeria. ${ }^{6}$ Coordinator, The Campaign Against Unwanted Pregnancy (The CAUP).

Correspondence: Dr Boniface Oye-Adeniran, Department of Obstetrics \& Gynaecology, College of Medicine, University of Lagos, Lagos, Nigeria.E-mail:bonifaceoye@yahoo.com;oye@,beta.linkserve.com
} 


\section{Introduction}

Unwanted pregnancy is the major precursor of abortion, most of which are unsafe in our environment. Abortion is a major contributor to maternal morbidity and mortality in our environment with its contribution estimated at about $22.540 \%$ of all maternal deaths in Nigeria. ${ }^{1,2}$ An estimated 610,000 abortions are reported to occur in Nigeria annually. ${ }^{3}$ Unwanted pregnancy occurs in women of all ages but adolescents have been most affected. ${ }^{4-}$ ${ }^{9}$ It has been reported that by the age of 45 years most women would have had at least one abortion. ${ }^{10}$ Married women also experience unwanted pregnancy, as they constituted $34.8 \%$ of abortion seekers in a study from Lagos. ${ }^{11}$ It has therefore been suggested that some women use abortion as a means of child spacing instead of contraception. ${ }^{11}$ This may be a result of the persistently low contraceptive prevalence rates despite reported high contraceptive awareness and enlightenment drives. ${ }^{1,11,12}$

It is obvious therefore that abortion is not prerogative or a problem of any single group of women. In spite of this, most studies on unwanted pregnancy and abortion have been hospital-based. The impact, prevalence and ways women deal with unwanted pregnancy in the community are driven more to the background. A few studies that have tried to assess the prevalence of unwanted pregnancy and abortion in the community ${ }^{1,3,11}$ have found that it presents a problem of considerable magnitude. There is a need to conduct collaborative studies of the profile in order to increase community awareness on the extent of the calamity. In a 1994 study to document the magnitude of unsafe abortion complications in Commonwealth member countries by the Commonwealth Regional Health Community Secretariat, one of the major research needs identified was community-based epidemiological studies. ${ }^{13}$ This study therefore seeks to study the prevalence of unwanted pregnancy in the community as well as associated factors including the views, perceptions and attitudes of community members towards unwanted pregnancy and the pattern of helpseeking behaviour on the problem.

\section{Methodology}

This community-based study of unwanted pregnancy was conducted in 1997 in more urban Lagos State and relatively more rural Edo State of Nigeria. Despite the restrictive law on abortion in Nigeria, women give information on induced abortion as evidenced by records from antenatal clinics. This is more so when trained interviewers are used and confidentiality is ensured as it was in this study.

The study was supported by the Nigerian Medical Association (NMA) and the Association of General and Private Medical Practitioners of Nigeria (AGPMPN).

Sample Size

Various factors were taken into consideration in determining the minimum sample size. Among them was the need for the study size to be able to address all the research objectives. For this reason, sample sizes were determined for each of the research objectives. Eventually, the largest sample size that satisfied all objectives was used. This was 
the objective that sought to compare the prevalence of abortion between Lagos and Edo States. The following formula for sample size expression for comparative studies was used: $\mathrm{n}=2 \mathrm{pq}\left\{\mathrm{Z}+\mathrm{Z}_{\mathrm{B}}\right)^{2} /\left(\mathrm{P}_{1}-\mathrm{P}_{0}\right)^{2}$

In this study, the level of confidence was specified at $95 \%$ and the power was fixed at $80 \%$. Specifications for $\mathrm{p}_{1}$ and $\mathrm{p}_{0}$ were based on information from available literature. The sample sizes determined for Lagos and Edo were 1,890 and 802 respectively. The final sample sizes were adjusted further to compensate for non-response rate of $20 \%$, thus the minimum for Lagos was 2,363 and 1,003 for Edo.

\section{Selection of Respondents}

The local government areas (LGAs) served as the primary sampling units (PSU). The LGAs were stratified into urban-rural, based on the National Population Commission criteria. There were twice as many LGAs in urban than in rural areas in Lagos State, whereas in Edo the reverse was the case. This disparity in the relative size of urban versus rural LGAs was taken into consideration in determining the number of enumeration areas (EAs) to be selected from each locality of a state. Fifty per cent random samples of the total number of rural and urban LGAs were selected. The list of EAs in the selected LGAs served as the sampling frame at the second stage sampling. An EA has a population of about 550 , out of which $20 \%$ would be women aged 15-49 years. It was therefore estimated that each EA would provide about 110 women with an average of about two women per household. If only one woman is selected per household then we would have about 55 women in each EA. The number of EAs needed to achieve our sample size was determined based on this. The number of EAs selected as a fraction of the total gave the sampling fraction and the inverse gave the sampling interval, which was used in selecting the required EAs. In each selected EA, all households were covered. Only one respondent was selected per household. In households with more than one eligible respondent, a ballot system was used to select one.

A standard questionnaire was used for data collection. It was pre-tested and administered by trained female field workers. A distinction between induced and spontaneous abortion was based on the question that sought to find out if the woman deliberately took any action in the process of stopping the pregnancy. The questionnaire instrument was developed with involvement of a consultant epidemiologist at the College of Medicine, University of Lagos, Nigeria. A total of 3,743 interviews (2,579 from Lagos State and 1,164 from Edo State) were successfully completed.

\section{Statistical Analysis}

For descriptive statistics and bivariate analysis, the Epi Info (version 6) was used. Multiple logistic regression analysis was undertaken to examine how selected independent variables were related to the likelihood of unwanted pregnancy and abortion while simultaneously controlling for possible confounders. The logistic programme was used for this purpose. Categorical attributes such as level of education, marital status and religion were converted to dichotomous variables for the purpose of logistic regression analysis. 


\section{Results}

A total of 3,743 respondents (2,579 from Lagos State and 1,164 from Edo) were involved in this survey.

\section{Socio-Demographic Characteristics of Respondents}

The majority of respondents $(60.1 \%)$ were below 35 years. The composition in each reproductive age category was fairly similar in both states, except that there were significantly $(\mathrm{p}<0.05)$ more teenage respondents in Lagos (17.1\%) than in Edo (14.1\%).

In Lagos State, $60.6 \%$ of the respondents were born in urban areas while in Edo State most of the respondents (61.8\%) were born in rural areas.

\section{Level of Education}

In Lagos, $35.1 \%$ of the respondents have completed secondary education and $14.4 \%$ had had post-secondary qualification, while in Edo the corresponding percentages were $26.0 \%$ and $11.2 \%$. In the two states, the percentage of illiterate respondents was about the same; $9.9 \%$ in Lagos and $12.1 \%$ in Edo. Husbands of the respondents on the other hand attained higher level of education in both states. Most of the husbands (about 65\%) were reported to have completed secondary education or above.

Of the 3,718 interviewees responding to question on occupation, 2,625 (70.6\%) were currently engaged in some form of economic activity. The most commonly mentioned economic activity in both states was trading. Other respondents were engaged in skilled and semi-skilled occupations such as fashion designing, hairdressing, catering, etc.

A large majority of the respondents (71.9\%) were Christians, while Muslims constituted $33.1 \%$ in Lagos and only $6.2 \%$ in Edo. Of the Christians in both states, the Pentecostals were in the majority.

\section{Marital Status}

Among the 3,712 respondents who supplied information on marital status, 2,346 (63.2\%) were married while $31.7 \%$ were never married. More than a quarter $(27.5 \%)$ of the married respondents were in polygamous homes.

\section{Awareness on Contraception}

While $91.3 \%$ (3,401 out of 3,724) had heard of ways or methods of preventing or avoiding pregnancy, some $(8.7 \%)$ had not, and 1,363 (36.6\%) had tried in some way to avoid or delay pregnancy. There was a statistically significant association between level of education and use of a method to avoid or delay pregnancy $(\mathrm{p}<0.001)$. Among respondents with no formal education, use rate was $27.6 \%$, while use rate increased to $34.4 \%$ and $51.7 \%$ among those with secondary and post-secondary education respectively. There was however no significant difference in use rate between primary and secondary school certificate holders. This pattern was consistent in both states.

Concerning current use, a significantly higher proportion of respondents in Lagos (25.1\%) were using a method, compared to $19.8 \%$ in Edo. Current use rate was also significantly related to respondents' level of education. Current use rate ranged from $17.8 \%$ among the illiterates to $29.7 \%$ among those with post-secondary 
education (Table 3). Christians were more likely than their Muslim counterparts to use a contraceptive method, but the difference was marginal and non-statistically significant. When examining the relationship between religion and parity, it was found that the Catholics and traditionalists, on the average, had more children than those in other religions/denominations.

\section{Experience with Unwanted Pregnancy}

A total of 988 (26.6\% of 3718 ) respondents have been pregnant when they did not want to be. The experience with unwanted pregnancy was significantly more common in Edo State (31.7\%) than in Lagos (24.3\%).

The reasons most commonly given in Lagos for not wanting the pregnancy (Table 2) were high cost of raising children $(23.8 \%)$, poor timing of pregnancies or short birth intervals $(22.3 \%)$ and desire to continue with education (19.9\%). In Edo the single most important reason was that respondents were unmarried and did not wish to be seen as unwed mothers (22.9\%). Desire to continue education (20.4\%) and poor birth spacing $(19.2 \%)$ were the other major reasons. Of the 975 respondents who had experienced unwanted pregnancies, 178 (18.3\%) became pregnant while using some form of contraception. Contraceptive failure rate was significantly higher in Edo (21.9\%) than in Lagos (16.1\%). Of those who became pregnant while using a method, 83 (46.1\%) were on the pill and $39(27.2 \%)$ were using the rhythm method.

Table 1 Contraceptive Prevalence by Level of Education

\begin{tabular}{lrrr}
\hline Level of education & $\begin{array}{r}\text { Number of } \\
\text { respondents }\end{array}$ & Number of current users & Prevalence (\%) \\
\hline No formal education & 394 & 70 & 17.8 \\
Part primary & 187 & 37 & 19.8 \\
Primary & 758 & 183 & 24.1 \\
Part secondary & 687 & 140 & 20.4 \\
Secondary completed & 1,206 & 295 & 24.5 \\
Post-secondary & 501 & 149 & 29.7 \\
Total & 3,733 & 874 & 23.4 \\
\hline
\end{tabular}

Table 2 Reasons Given by Respondents for not Wanting the Pregnancy

\begin{tabular}{|c|c|c|c|c|c|c|}
\hline \multirow[t]{2}{*}{ Reason } & \multicolumn{2}{|c|}{$\operatorname{Lagos}(n=613)$} & \multicolumn{2}{|c|}{ Edo $(n=363)$} & \multicolumn{2}{|c|}{ Total $(N=976)$} \\
\hline & No. & $\%$ & No. & $\%$ & No. & $\%$ \\
\hline $\begin{array}{l}\text { Economic reasons (high } \\
\text { cost of raising children) }\end{array}$ & 146 & 23.8 & 50 & 13.8 & 196 & 20.1 \\
\hline $\begin{array}{l}\text { Too soon after last } \\
\text { pregnancy }\end{array}$ & 137 & 22.3 & 69 & 19.0 & 206 & 21.1 \\
\hline $\begin{array}{l}\text { Education would be } \\
\text { interrupted }\end{array}$ & 122 & 19.9 & 74 & 20.4 & 196 & 20.1 \\
\hline Too young & 36 & 5.9 & 26 & 7.2 & 62 & 6.4 \\
\hline Not married & 86 & 14.0 & 83 & 22.9 & 169 & 17.3 \\
\hline Extram arital relationship & 9 & 1.5 & 11 & 3.0 & 20 & 2.0 \\
\hline Abandoned by partner & 9 & 1.5 & 3 & 0.8 & 12 & 1.2 \\
\hline $\begin{array}{l}\text { Has completed the } \\
\text { desired family size }\end{array}$ & 25 & 4.1 & 25 & 6.9 & 50 & 5.1 \\
\hline Others & 43 & 7.0 & 22 & 6.1 & 65 & 6.7 \\
\hline
\end{tabular}




\section{Prevalence of Abortion}

The prevalence of abortion was $27.1 \%$ in Edo and $19.2 \%$ in Lagos. The difference was statistically significant $\left(\mathrm{x}^{2}=29.9 ; \mathrm{p}<0.001\right)$. This difference in abortion prevalence between Lagos and Edo States was not confounded by age or level of education, as the crude odds ratio remained stable after adjustment. The prevalence of abortion in both states was strongly related to the level of education of the respondents as shown in Tables $5 \mathrm{a}$ and $5 \mathrm{~b}$.

The prevalence of abortion increased with increasing level of education in both states. It was also observed that some of the attempts at termination did not succeed. Failure rate (Table 3) was related to the respondents' level of education. It was highest (12.5\%) among those with no formal education and lowest $(0.0 \%)$ among those with post-secondary education.

Prevalence was lowest among teenage respondents and highest among women between the ages of 25 and 34 years. The prevalence of abortion was consistently lower among Muslims than Christians. Among the Christians, abortion prevalence was fairly evenly distributed among the different denominations.

\section{Decision to Stop a Pregnancy}

The decision to stop a pregnancy was in majority of the cases (47.6\%) made by both the man and the woman. In $38 \%$ of the cases, the decision was made solely by the woman, and in $10.5 \%$ the male partner independently made the decision. The decision-making

Table 3 Respondents' Level of Education and Prevalence of Abortion in Lagos and Edo States

\begin{tabular}{lrrrrrr}
\hline Level of education & No. of respondents & \multicolumn{3}{c}{$\begin{array}{c}\text { No. with history of } \\
\text { abortion }\end{array}$} & \multicolumn{2}{c}{ Prevalence (\%) } \\
& Lagos & Edo & Lagos & Edo & Lagos & Edo \\
\hline No formal education & 254 & 140 & 19 & 16 & 7.5 & 11.4 \\
Part primary & 90 & 97 & 11 & 17 & 12.2 & 17.5 \\
Primary & 481 & 277 & 82 & 53 & 17.0 & 19.1 \\
Part secondary & 472 & 215 & 70 & 60 & 14.8 & 27.9 \\
Secondary completed & 904 & 302 & 198 & 104 & 21.9 & 34.3 \\
Post-secondary & 371 & 130 & 114 & 67 & 30.7 & 51.5 \\
Total & 2,572 & 1,161 & 494 & 317 & 19.2 & 27.3 \\
\hline
\end{tabular}

Table 4 Failed Attempts to Stop a Pregnancy by Level of Education

\begin{tabular}{lrrr}
\hline Level of Education & $\begin{array}{r}\text { No. of respondents } \\
\text { who attempted }\end{array}$ & No.of failures & $(\%)$ \\
\hline No formal education & 40 & 5 & 12.5 \\
Part primary & 30 & 2 & 6.7 \\
Primary & 141 & 6 & 4.3 \\
Part secondary & 131 & 1 & 0.8 \\
Secondary completed & 306 & 4 & 1.3 \\
Post-secondary & 181 & 0 & 0.0 \\
Total & 829 & 18 & 2.2 \\
\hline
\end{tabular}


pattern was similar in Edo and Lagos States. Some $80.4 \%$ of the respondents had informed their male partners of the plan to terminate the pregnancy. Among those respondents who had experienced unwanted pregnancy, nearly half (46\%) had more than one experience and many had terminated more than three pregnancies.

\section{Timing of Termination}

Almost all the terminations (98.4\%) took place within the first three months of the pregnancy. There were, however, cases where the pregnancies were terminated after the fourth month (1.6\%). An overwhelming majority of the terminations (78\%) were done at private clinics or hospitals (Table 5). Respondents from Edo State were more likely to use traditional healers, chemist operators
$23 \%)$. Cost consideration was a rather insignificant determinant of the choice.

\section{Methods Used to Terminate Pregnancies}

Dilatation and curettage (D \& C) was the most common (43.3\%) technique used to terminate pregnancies (Table 6). Medical practitioners largely did the terminations. Nurses, traditional healers and chemist operators were involved in $6.3 \%, 4.2 \%$ and $2.8 \%$ of the cases respectively. Advice on contraception was provided to $55 \%$ of patients in Lagos and $40.9 \%$ in Edo.

\section{Abortion-Associated Complaints}

Complaints and complications following abortion were significantly $(\mathrm{p}=0.012)$ more common in Edo (17.5\%) than Lagos (11.2\%).

Table 5 Place where Pregnancies Were Terminated by Respondents

\begin{tabular}{lrrrrrr}
\hline Place & \multicolumn{2}{c}{ Rural $(\mathbf{n}=\mathbf{1 1 6})$} & \multicolumn{2}{c}{ Urban $(\mathbf{n}=\mathbf{7 0 3})$} & \multicolumn{2}{c}{ Total $(\mathbf{N}=\mathbf{8 1 9})$} \\
& No. & $\mathbf{\%}$ & No. & \% & No. & \% \\
\hline Traditional healer & 7 & 6.0 & 6 & 0.9 & 13 & 1.6 \\
Private clinic/hospital & 71 & 61.2 & 568 & 80.8 & 639 & 78.0 \\
Government clinic/hospital & 22 & 19.0 & 29 & 4.1 & 51 & 6.2 \\
Chemist & 7 & 6.0 & 16 & 2.3 & 23 & 2.8 \\
Maternity/nursing home & 1 & 0.9 & 19 & 2.7 & 20 & 2.4 \\
Doctor's home & 5 & 4.3 & 28 & 4.0 & 33 & 4.0 \\
Respondent's home & 2 & 1.7 & 33 & 4.7 & 35 & 4.3 \\
Others & 1 & 0.9 & 4 & 0.6 & 5 & 0.6 \\
\hline
\end{tabular}

Reasons for Choosing a Place for Pregnancy Termination

Quality of service was the most important factor in the choice of a place for pregnancy termination in both states, accounting for 29.3\% and 35.4\% in Lagos and Edo States respectively. The next most important factor was direction by a friend (Lagos 27\%, Edo
The most commonly reported complaints following abortion were pain (41\%), followed by bleeding (32.5\%) and infection (14.5\%). Of those 105 patients with complaints, 85 $(81 \%)$ were given some form of treatment mainly at private clinics/hospitals. 
110 African Journal of Reproductive Health

Perceived Frequency of, and Reasons for Abortion in the Community

More than half (53.2\%) of Edo respondents considered abortion rates to be high or very high in their respective communities, while only $27.1 \%$ thought so in Lagos. Economic reasons (high cost of raising children) were

often cited as reasons women make use of abortion services. A second important reason was that these women are single and would not want to be seen as unwed single mother.

Respondents were of the opinion that pregnancy could be safely terminated by a qualified medical practitioner and that the decision to stop a pregnancy should be jointly made by both partners.

Table 6 Methods Used to Terminate Pregnancies

\begin{tabular}{lrrrrrr}
\hline Methods & \multicolumn{2}{c}{ Lagos } & \multicolumn{2}{c}{ Edo } & \multicolumn{2}{c}{ Total } \\
& No. & \% & No. & \% & No. & \% \\
\hline Manual vacuum aspiration & 102 & 20.6 & 78 & 24.4 & 180 & 22.1 \\
Electric vacuum aspiration & 2 & 0.4 & 9 & 2.8 & 11 & 1.3 \\
Injection & 22 & 4.4 & 7 & 2.2 & 29 & 3.6 \\
Tablets & 16 & 3.2 & 21 & 6.6 & 37 & 4.5 \\
Dilatation and curettage & 209 & 42.1 & 144 & 45.0 & 353 & 43.3 \\
Under anaesthesia & 47 & 9.5 & 23 & 7.2 & 70 & 8.6 \\
Don't know & 83 & 16.7 & 25 & 7.8 & 108 & 13.2 \\
Others & 15 & 3.0 & 13 & 4.1 & 28 & 3.4 \\
\hline
\end{tabular}

Table 7 Reasons Women Had Abortion

\begin{tabular}{lrrrrrr}
\hline Reasons & \multicolumn{2}{c}{ Lagos $(\mathbf{n}=\mathbf{2 , 5 6 9 )}$} & \multicolumn{2}{c}{ Edo $(\mathbf{n}=\mathbf{1 , 1 5 8})$} & \multicolumn{2}{c}{ Total $(\mathbf{N}=\mathbf{3 , 7 2 7})$} \\
& No. & \% & No. & \% & No. & \% \\
\hline Contraceptive failure & 52 & 2.0 & 21 & 1.8 & 73 & 2.0 \\
Economic reasons & 669 & 26.0 & 383 & 33.1 & 1052 & 28.2 \\
Too soon after last & 113 & 4.4 & 65 & 5.6 & 178 & 4.8 \\
pregnancy & & & & & & \\
Education apprenticeship & 239 & 9.3 & 107 & 9.2 & 346 & 9.3 \\
Too young & 220 & 8.6 & 72 & 6.2 & 292 & 7.8 \\
Not married & 335 & 13.0 & 181 & 15.6 & 516 & 13.8 \\
Extramarital relationship & 102 & 4.0 & 22 & 1.9 & 124 & 3.3 \\
Don't know & 666 & 25.9 & 230 & 19.9 & 896 & 24.0 \\
Others & 173 & 6.7 & 77 & 6.6 & 250 & 6.7 \\
\hline
\end{tabular}

Table 8 Person Who Terminated Pregnancy

\begin{tabular}{lrrrrrr}
\hline Person & \multicolumn{2}{c}{ Lagos $(\mathbf{n}=\mathbf{4 9 8})$} & \multicolumn{2}{c}{ Edo $(\mathbf{n}=\mathbf{3 1 8})$} & \multicolumn{2}{c}{ Total $(\mathbf{N}=\mathbf{8 1 6})$} \\
& No. & $\mathbf{\%}$ & No. & \% & No. & \% \\
\hline Doctor & 425 & 85.3 & 269 & 84.6 & 694 & 85.0 \\
Chemist & 13 & 2.6 & 10 & 3.1 & 23 & 2.8 \\
Nurse & 37 & 7.4 & 16 & 5.0 & 53 & 6.5 \\
Traditional healer & 1 & 0.2 & 9 & 2.8 & 10 & 1.2 \\
Self & 22 & 4.4 & 13 & 4.1 & 35 & 4.3 \\
Others & 0 & 0.0 & 1 & 0.3 & 1 & 0.1 \\
\hline
\end{tabular}


Table 9 Place Where Treatment was Received for Abortion Complications

\begin{tabular}{|c|c|c|c|c|c|c|}
\hline \multirow[t]{2}{*}{ Place } & \multicolumn{2}{|c|}{ Lagos $(n=44)$} & \multicolumn{2}{|c|}{ Edo $(n=41)$} & \multicolumn{2}{|c|}{ Total $(n=85)$} \\
\hline & No. & $\%$ & No. & $\%$ & No. & $\%$ \\
\hline Traditional healer & 0 & 0.0 & 4 & 9.8 & 4 & 4.7 \\
\hline Traditional birth attendant & 0 & 0.0 & 0 & 0.0 & 0 & 0.0 \\
\hline Private clinic & 29 & 65.9 & 25 & 61.0 & 54 & 63.5 \\
\hline Government clinic & 8 & 18.2 & 2 & 4.9 & 10 & 11.8 \\
\hline Chemist & 0 & 0.0 & 10 & 24.4 & 10 & 11.8 \\
\hline Maternity & 2 & 4.5 & 0 & 0.0 & 2 & 2.4 \\
\hline Private residence & 0 & 0.0 & 0 & 0.0 & 0 & 0.0 \\
\hline Others & 5 & 11.4 & 0 & 0.0 & 5 & 5.9 \\
\hline
\end{tabular}

Table 10 Logistic Regression Analysis Showing the Relationship between Selected Independent Variables and the Likelihood of Unwanted Pregnancy

\begin{tabular}{|c|c|c|c|c|}
\hline Variable & $\begin{array}{r}\text { Regression } \\
\text { coefficient }\end{array}$ & Odd ratio & $\begin{array}{r}95 \% \text { CI for } \\
\text { OR }\end{array}$ & P value \\
\hline Constant & -0.742 & & & \\
\hline Age & 0.112 & 1.12 & $1.04-1.20$ & $0.002 *$ \\
\hline Marital status (married $=1$, else $=0$ ) & -0.909 & 0.40 & $0.27-0.60$ & $<0.001 *$ \\
\hline Religion $($ Christian $=1$, others $=0)$ & -0.161 & 0.85 & $0.06-1.20$ & 0.359 \\
\hline Locality $($ urban $=1$, rural $=0)$ & -0.238 & 0.79 & $0.55-1.12$ & 0.185 \\
\hline $\begin{array}{l}\text { Education (secondary }=1 \text {, less than } \\
\text { secondary }=0 \text { ) }\end{array}$ & 0.620 & 1.86 & $1.44-2.40$ & $<0.001 *$ \\
\hline $\begin{array}{l}\text { Education of husband (secondary }=1 \text {, } \\
\text { less than secondary }=0 \text { ) }\end{array}$ & 0.186 & 1.20 & $0.40-1.60$ & 0.205 \\
\hline
\end{tabular}

Factors significantly related to the livelihood of unwanted pregnancy after controlling for confounders were age, marital status and level of education.

The educational level of the spouse was also positively associated with the risk of unwanted pregnancy but the association was not statistically significant $(\mathrm{p}=0.205)$.

For abortion, the two factors that remained significant after controlling for confounders were marital status and level of education. Unmarried respondents were two times more likely to be involved in pregnancy termination than their married counterparts.

Those with secondary education and above were also more likely $(\mathrm{OR}=2.0)$ to be involved in abortion than the less educated respondents. 
Table 11 Logistic Regression Analysis Showing the Relationship between Selected Independent Variables and the Likelihood of Induced Abortion

\begin{tabular}{lrrrr}
\hline Variable & $\begin{array}{r}\text { Regression } \\
\text { coefficient }\end{array}$ & Odd ratio & 95\% CI for OR & P value \\
\hline Constant & -1.2318 & & & \\
Age & 0.0512 & 1.05 & $0.97-1.14$ & 0.208 \\
Marital status (married =1, else=0) & -0.6880 & 0.50 & $0.33-0.77$ & $0.002^{*}$ \\
Religion (Christian =1, others =0) & -0.2825 & 0.75 & $0.51-1.11$ & 0.151 \\
Locality (urban =1, rural =0) & -0.2713 & 0.77 & $0.52-1.11$ & 0.156 \\
Education (secondary =1, less than & 0.6976 & 2.01 & $1.51-2.67$ & $<0.001^{*}$ \\
Secondary =0) & & & & \\
Education of husband (secondary =1, & 0.3505 & 1.42 & $1.02-1.97$ & 0.351 \\
Lessthan secondary =0) & & & &
\end{tabular}

\section{Discussion}

The prevalence of unwanted pregnancy of $26.6 \%$ in this study was significantly higher than $19 \%^{14}$ and $21.7 \%^{11}$ reported in earlier studies from Lagos in 1980 and 1982 respectively and $20 \%$ reported from Jos and Ife in 1996. However, it was much lower than $43.6 \%$ reported from Ghana. ${ }^{15}$ The abortion prevalence of $21.7 \%$ in this study was far higher than $5.6 \%$ and $5.0 \%$ from the Lagos studies. The previous reports had acknowledged the probability of gross underreporting of the incidence of abortion in that study. It is probable that with the steps taken in this study it was possible to ensure more confidentiality and get more respondents to be forthcoming with information on abortion. It is also true that more people, with enlightenment, can speak much more freely on the subject of unwanted pregnancy and abortion once they are ensured of confidentiality. Even at that, because of adverse societal perception of abortion, it is still probable that some women may not have owned up to induced abortion; therefore, the actual figure may be more than reported. It is also possible that there has been an actual increase in the abortion prevalence over the years.

Abortion was significantly more prevalent among respondents from Edo (27.1\%) than Lagos State (19.2\%) and was not confounded by age or levels of education. This may be reflective of the lower levels of contraceptive use and resort to abortion to solve the problem of unwanted pregnancy. ${ }^{46-}$ 18

Education appeared to play a significant role in abortion as the prevalence of abortion increased with increasing level of education. This is similar to earlier reports from Nigeria and Ghana., ${ }^{1,15}$ More educated women probably wish to pursue careers or further their education, which pregnancy may interrupt. In this study, interruption of education accounted for $20.1 \%$ of the reasons respondents did not want their pregnancy. Those without formal education may not even realise that they are pregnant until it has become too late, and they may not be able to 
negotiate with their spouses with regards to safe sex. This is also ironical because one would have expected the more educated respondents to be more aware of contraception; the risks of unprotected sexual intercourse and unsafe abortion and as such take steps to prevent it. Doctors provided abortion services for a large majority of unwanted pregnancies (85\%), which is consistent with findings from other studies in the country. ${ }^{3,19-21}$

Economic reasons, interruption of education, too soon after last pregnancy and being unmarried were the commonest reasons given for terminating unwanted pregnancy. For sexually active adults, all these are also reasons for which effective contraception would be recommended. Similar findings were reported from Lagos ${ }^{11}$ and Ghana ${ }^{15}$, where socio-economic reasons were most commonly cited for terminating unwanted pregnancy. These are all preventable situations that would be much cheaper to control with contraception than the abortion to which most resorted.

The large majority of the respondents (63.2\%) were married and they also contributed significantly to the prevalence of abortion. This further supports findings from other studies that the problem of unwanted pregnancy and abortion affects women of all ages and marital status. ${ }^{1,2}$ The adolescents and young persons, however, gain prominence in unsafe abortion because of their poor financial empowerment and often illicit and spontaneous nature of the sexual act itself. They tend to seek help from unskilled abortion care providers, while the married women may get help from their husbands and so seek safe abortion services.
Majority of the respondents $(91.3 \%)$ were aware of some methods of contraception. This compares with $95.2 \%$ reported from Lagos. ${ }^{11}$ Despite this high level of awareness, only $36.6 \%$ of women had tried contraception at some point, showing a great gap between awareness and usage. The overall conclusion would be that knowledge does not directly translate into attitudinal change where contraceptive usage is concerned. ${ }^{6,11}$ Further research is therefore necessary to study the possible factors that could affect this change. Possible factors that need to be investigated include fear of side effects, misinformation on contraception, spousal disapproval, and fear of being labelled as wayward for using contraception, among others. ${ }^{12,17,18}$ Also, despite the high association between education and use rate of contraception this same group also had a high association with abortion. This compares with similar findings from Lagos and other parts of the world, indicating that women who had used contraception are more likely to have had abortion than women who had not used contraception. ${ }^{1,11}$ The prevalence of abortion was lower among Moslems in this study despite the fact that the larger majority of the study population in the study area are Christians.

Interestingly, cost $(3.5 \%)$ was not a consideration in the choice of a place for termination of pregnancy as was the consideration of quality of service (35.4\%). This is probably the reason many among them are alive today to partake in the study! Those who had unsafe abortion would probably have suffered mortality. Friends played a significant role $(25.6 \%)$ in the choice of a facility for termination of pregnancy. This 


\section{African Journal of Reproductive Health}

compares with other reports in which peer groups have been identified as playing significant roles in unwanted pregnancy and induced abortion. ${ }^{22}$ Hence, strategies to combat unwanted pregnancy and unsafe abortion must target these groups generally in order to ensure effective dissemination of information.

Finally, $35.2 \%$ of women rate the prevalence of abortion as being high or very high in the community.

In conclusion, unwanted pregnancy constitutes a problem even at the community level, and the high contraceptive awareness should be translated to an increased use in order to bridge the large gap of unmet need. This is a task for policymakers, nongovernmental organisations, community leaders, health professional bodies and family planning service providers. Increased contraceptive use will reduce the prevalence of unwanted pregnancy and induced abortion, with all the inherent complications, when performed clandestinely by unskilled abortion care providers under the current restrictive legal environment in Nigeria.

\section{Acknowledgement}

We wish to acknowledge the invaluable contributions of our consultants, supervisors and field staff in the planning and conduct of this study. The John D. and Catherine T. MacArthur Foundation (Grant No. 27895) supported the study. The findings and conclusions are those of the authors and do not necessarily represent the views of The John D. and Catherine T. MacArthur Foundation.

\section{REFERENCES}

1. Okonofua FE, Odimegwu E, Ajabor H, et al. Assessing the prevalence and determinants of unwanted pregnancy and i $\mathrm{n} \mathrm{d} \mathrm{u} \mathrm{c} \mathrm{e} \mathrm{d}$ abortion in Nigeria. StudFam Plann 1999; 30(1): 67-77.

2. Emuveyan EE and Agboghoroma OC. Trends in abortion related maternal mortality in Lagos, Nigeria. TropJ Obstet Gynaecol 14(1): 39-41.

3. Henshaw SK, Singh S, Oye-Adeniran BA, Adewole IF, Iwere $\mathrm{N}$ and Cuca YP. The incidence of induced abortion in Nigeria. Int Fam Plann Persp 1998; 24(4); 156-164.

4. Omu AE, Oronsanye AU, Fall MKB and Asuquo EJ. Adolescent induced abortion in Benin City, Nigeria. Int J Gynaecol Obstet 1987; 19: 495-499.

5. Adetoro OO, Babarinsa $\mathrm{AB}$ and Sotiloye OS. Sociocultural factors in adolescent septic illicit abortions in Ilorin, Nigeria. Afr J Med Sci 1991; 20(2): 149-153.

6. Adewole IF, Oye-Adeniran BA, Iwere $\mathrm{N}$, Oladokun A, Gbadegesin A and Babarinsa AI. Contraceptive usage among abortion seeker in Nigeria. W AfrJMed2002;21(2): 112-114.

7. Archibong EI. Illegal induced abortion, a continuing problem in Nigeria. Int J Gynaecol Obstet 1991;34(2):261-265.

8. Odujunrin OMT. Sexual activity, contraceptive practice and abortion among adolescents in Lagos, Nigeria. Int J Gynaecol Obstet 1991; 34:361366.

9. Okpani AOU and Okpani JU. Sexual activity and contraceptive usage among female adolescents. A report from Port Harcourt, Nigeria. AfrJ Reprod Health 2000; 4(1): 40-47.

10. Alan Guttmacher Institute. Sharing Responsibility: 
Women, Society and Abortion Worldwide. New York: The Alan Guttmacher Institute, 1999.

11. Olukoya AA. Pregnancy termination: results of a community-based study in Lagos. Int J Gynaecol Obstet 1987; 25: 41-46.

12. Onuzurike BK and Uzochukwu BSC. Knowledge, attitude and practice of family planning amongst women in a high density low income urban of Enugu, Nigeria. Afr J Reprod Health 2001; 5(2): 83-89.

13. Benson J, Nicholson LA, Gaffikin L and Kinoti SN. Complications of unsafe abortion in subSaharan Africa: a review. Health Policy Plan 1996; 11(2): 117-131.

14. Makinwa-Adebusoye PK, Nichols DJ and Kelly SE. Lagos Contraception and Breastfeeding Study, Final Report. Center for Social Culture and Environmental Research, University of Benin, Benin City, Nigeria, 1982.

15. Geelheod D, Nayembil D, Asare K, Van Leeuwen JH and Van Roosmalen J. Gender and unwanted pregnancy: a community-based study in rural Ghana. J Obstet Gynaecol2002; 23(4): 249255.

16. Unuigbe IE and Ogbeide Osafu. Sexual behaviour and perception of AIDS among adolescent girls in Benin City, Nigeria. Afr J Reprod Health 1999; 3(1):39-44.

17. Aziken ME, Okonta PI and Ande BAA. Knowledge and perception of emergency contraception among female Nigerian undergraduates. Int Fam Plann Persp 2003; 29(2): 84-87.

18. Otoide VO, Oronsanye F and Okonofua FE. Why Nigerian adolescents seek abortion rather than contraception: evidence from focus group discussions. Int Fam Plann Persp 2001; 27(2): 7781 .

19. Adewole IF, Oye-Adeniran BA, Iwere $\mathrm{N}$, Oladokun A and Gbadegesin A. Terminating an unwanted pregnancy the economic implications in Nigeria.J Obstet Gynaecol2002; 22(4): 436-437.

20. Megafu U and Ozumba BC. Morbidity and mortality from induced illegal abortion at the University of Nigeria Teaching Hospital, Enugu: a five-year review. Int J Gynaecol Obstet 1991; 34: 163-167.

21. Adewole IF. Trends in postabortal mortality and morbidity in Ibadan, Nigeria. Int $J$ Gynaecol Obstet 1992; 38(2): 115-118

22. Unuigbe IE and Ogbeide Osafu. Sexual behaviour and perception of AIDS among adolescent girls in Benin City, Nigeria. Afr J ReprodHealth 1999; 3(1):39-44. 